\title{
Guaranteed Protection that should be for Children's Civil Rights after their Parents Divorce
}

\author{
Surjadi Sjamsir ${ }^{1}$, Riswadi $^{2}$ \\ University of Borobudur ${ }^{1,2}$ \\ \{surjadisjamsir@gmail.com¹, riswadi@borobudur.ac.id ${ }^{2}$ \}
}

\begin{abstract}
Child protection efforts need to be implemented as early as possible, namely from pregnancy until the child is eighteen years old. The approach used in this study is normative-empirical, namely legal research on the implementation or implementation of normative legal provisions in action on every particular legal event that occurs in society. Parental responsibility after a divorce, both parents should realise how important the responsibility of parents to their children is morally, traditionally and religiously. The parent should provide for the child.
\end{abstract}

Keywords: Child Protection; Parental Divorce; Civil Rights

\section{Introduction}

The child in a family is the fruit of love from parents as the successor of offspring, is a gift and at the same time a mandate from God Almighty, which must always be maintained because in him attached dignity, dignity, rights as a human being that must be respected and upheld. In QS. Al Baqarah: 233, it is contained how a child gets the protection of his life rights under the obligations that must be fulfilled by the parents of the man (father) and the obligations of the parents of the woman (mother) according to the ability. Allah SWT. Balancing relationships in one whole family wherein QS. Al-Isra: 23.24 mentioned the obligation of a child to his parents, including ethics to parents.

Children's rights are part of the human rights contained in the 1945 Constitution (Supriyanto, 2020) and the United Nations Convention on the Child's Rights. In national and state life, children's existence is fundamental as the next generation prepared to receive the leadership relay stick in the future. To get a quality generation, every child is entitled to survival, growth and development, and is entitled to protection from violence and discrimination.

Therefore, parents, families, and communities are responsible for safeguarding and maintaining the child's human rights under the rights and obligations attached to his/her humanitarian values. Similarly, in child protection, the state and government are responsible for providing accessibility for children, especially in ensuring optimal and targeted growth and development. Thus the child as the next generation has a formidable potential, good nationalism, and noble character. Accountability for the fulfilment of children's rights by parents, families, communities, and governments and countries is a series of activities carried out continuously to protect children's rights. The series of activities must be sustainable and 
directed to ensure children's growth and development, both physical, mental, spiritual and social.

Child protection efforts need to be implemented as early as possible, namely from pregnancy until the child is 18 (eighteen) years old. Based on the conception of complete, comprehensive and comprehensive child protection, the Child Protection Act. The obligation to protect the child based on the principles of non-discrimination, the child's best interests, the right to life, survival, development, and respect for the child's opinion.

Furthermore, Law No. 35 of 2014 on Amendments to Law No. 23 of 2002 on Child Protection in Article 14 paragraph (1) specifies that every child is entitled to be cared for by his parents unless there is a valid reason or the rule of law indicating that the separation is in the best interests of the child and is a final consideration; Article 14 paragraph (2) specifies that in the event of a separation the child remains entitled to meet directly and in regular personal contact with both parents and obtain the care and maintenance, education and protection of separation outlined in the birth certificate; and article 4 affirms that every child has the right to live, grow, develop, and participate reasonably under the dignity and dignity of humanity, and to be protected from violence and discrimination.

Normative efforts to protect the rights of the child are in line with the Convention on the Rights of the Child (Conventionon the Rights of the Child), which has been ratified by the Government of the Republic of Indonesia with Presidential DecreeNo. 36 of 1990, which states that the basic principles of child protection, among others, are non-discrimination and the best interest of the child. However, not all children get protection for their human rights because there are still children who have not fulfilled their rights, neglected by their parents, and do not get severe treatment from the government.

A whole and harmonious family is an environment where a child can obtain his rights in maintenance and optimal education. The opposite will happen when the family condition is not balanced, even leads to divorce that separates family members from each other. Husbandwife relationships that break up due to divorce emotionally will adversely affect the guaranteed welfare of the child.

A child is a child born of a loving relationship and a biological relationship between men and women. If the child's body flows blood and his parents' genetic traits, then there is no term ex-father or mother for a child. Law No. 1 of 1974 article 41 on the consequences of divorce has set the provisions on women's mandatory parties (mothers). The men (fathers) still maintain and educate children even though they are declared legally divorced as husband and wife on the court's decision. The father is responsible for all maintenance and education costs required of the child. If the father can not give the obligation, the court can determine that the mother is in charge of the price.

The child is an issue that has always been the concern of various elements of society, how his position and rights in the family and how he should be treated by his parents, even in public and state life, through his policies in protecting the child. The biological father is obliged to provide for the support of his biological child. A child once born is entitled to a living from his father both clothes, shelter, and other needs even though the child's parents' Marriage has broken up. For children born, his parents' divorce will shake his life and adversely affect his growth and development, so usually, children are the party that suffers the most from their parent's divorce.

The basis of the father's obligation to provide for the child and the relationship nasab also because the condition of the child who is not independent and requires spending, his life depends on the party responsible for guaranteeing his life. The person closest to the child is the father and mother, and if the mother is responsible for the care of the child at home, then 
the father is responsible for making his child's living. The father is only obliged to provide for his biological child as long as they require a living. He is not obliged to provide for his son, who has a property to finance himself. On the contrary, children should do good and serve their parents sincerely, and it is the parents who are the reason for their birth into the world.

If the parents' family are good, get along well and care, the child will get a positive element of his personality. If his parents are religious and obedient to carry out religion in daily life, they get a spiritual experience that becomes an element in his nature. Article 9 of Law No.4 of 1979 on child welfare states that parents are the first to be responsible for realising children's interest both physically, physically and socially. Parental responsibility for the welfare of the child contains the obligation to nurture and educate the child in such a way so that the child can grow and develop into an intelligent, healthy, devoted person to the parents, virtuous, godly to God almighty and willful, and able to continue the ideals of the nation based on Pancasila.

\section{Methodology}

The approach used in this study is normative-empirical, namely legal research on the application or implementation of normative legal provisions in action on every particular legal event that occurs in society (empirical facts). Use a research type library. This library research is conducted by searching, collecting, and studying legislation and other legal materials related to research objects.

\section{Result and Discussion}

\subsection{Divorce Trial Process at the Religious Court}

The process of examining civil cases, including divorce cases, consists of at least eight hearings that include:

a. Trial 1 Divorce. Session 1 is examining the parties' identity, the reading of the letter of claim and the recommendation of peace, meaning that before the reading of the letter of claim, the judge must actively and earnestly try to reconcile the two parties as long as the case has not been decided, efforts to negotiate it can be made at any examination hearing in the peace council. If it turns out that the peace effort was not successful, then the trial can be continued to the reading stage of the lawsuit. At the scene of reading the case, the plaintiff has the right to re-examine whether all the material listed in the evidence and petite is correct and complete. The matters listed in the letter of claim that is the reference or object of examination and examination should not be out of the scope contained in the letter of claim.

b. 2nd Divorce Hearing. Session 2 is the defendant's answer, and this happens if peace is not achieved at the first stage of the trial. In the defendant's response, the submission can be a confession that justifies the plaintiff's lawsuit's content either in whole or in part. It can also be a rebuttal to the lawsuit's scope along with its reasons or even filed a reconvention or counter-claim.

c. Trial 3 Divorce. Trial 3 is Replik, meaning that the plaintiff can reaffirm his claim denied by the defendant and defend himself for the defendant's attacks. At this stage, the plaintiff 
may retain the suit and add information deemed necessary to clarify the evidence or change the attitude by correcting the defendant's answer or rebuttal.

d. Trial 4 Divorce. Trial 4 is Duplik, meaning it is a stage for the defendant to explain the answer that the plaintiff denied repeatedly. Replik and duplik (answer-jinawab) can be done often until there is a meeting point between the plaintiff and the defendant and if the judge has considered enough but there are still things that are not agreed by the claimant and the defendant so that the need to prove the truth then the schedule is continued with the stage of proof.

e. Trial 5 Divorce. Trial 5 is the evidentiary stage that is the stage for the plaintiff to submit all evidence tools to support his lawsuit's evidence, likewise, against the defendant, who was allowed to introduce evidence tools to help his answer or refutation.

f. Trial 6 divorce. Session 6 is the conclusion of the parties. At this stage, both the plaintiff and the defendant are given the same opportunity to submit a final opinion on the outcome of the examination during the hearing, in their respective views.

g. Trial 7 divorce. Trial 7 is the verdict stage. At this stage, the judge formulates a sitting case and legal considerations (the judge's opinion) on the matter accompanied by the reasons and legal basis, which ends with the judge's decision on the case he examined. This judge decides to terminate the dispute of the parties.

In the case of divorce, there are known two terms in Islam: Divorce, Divorce and Divorce Gugat. Divorce Divorce is a divorce lawsuit filed by the husband to his wife, while Divorce Gugat is a divorce lawsuit filed by the wife. While the resulting verdict in the proceedings, there are two kinds of Convention Verdicts and Rekovensi Verdicts. The Award of the Convention is the award of the material of the original or preliminary lawsuit that is not denied by the defendant, in which the judge grants part or all. At the same time, the Decision of the Rekovensi is the term of the award of the material of the defendant's counter clad claim to the plaintiff, in which the judge grants part or all.

\subsection{Civil Rights of Children After Divorce of Both Parents}

The child is an issue that has always been the concern of various elements of society, how his position and rights in the family and how he should be treated by his parents, even in public and state life, through his policies in protecting the child. The biological father is obliged to provide for the support of his biological child. A child once born is entitled to a living from his father both clothes, shelter, and other needs even though the child's parents' Marriage has broken up. Article 1 paragraph (a) and paragraph (a) of the law. No.1, the year 1974 on Marriage is a legal guarantee of the rights of the child. However, for children born, his parents' divorce will shake his life and adversely affect his growth and development, so usually, children are the party that suffers the most from the divorce of his parents.

The basis of the father's obligation to provide for the child and the relationship nasab also because the condition of the child who is not independent and requires spending, his life depends on the party responsible for guaranteeing his life. The person closest to the child is the father and mother. If the mother is responsible for the child's care at home, the father is responsible for making his child's living. On the contrary, children should do good and serve their parents sincerely. It is the parents who are the reason for their birth into the world.

If classified, children's rights can be categorised into four large groups, namely the right to live, the right to grow and develop, the right to protection, and the right to participate. In Islamic teachings, there are two periods of child development with parental custody, namely the period before mumayyiz (the child has not been able to distinguish between the beneficial 
and the dangerous for himself, from birth to the age of seven or eight years) according to the Compilation of Islamic Law until the age of 12 years, (Article $106 \mathrm{KHI}$ ) and after mumayyiz. Before the child mumayyiz, the mother is more entitled to exercise custody of the child because the mother better understands the child's needs with compassion, let alone the child desperately needs to live nearby.

Mumayyiz period begins since the child has been able to distinguish which one is dangerous and beneficial to him. There starts from seven years until the end of adulthood (balig sensible). At this time, the child can choose and decide whether to join his mother or father. But under certain circumstances, when the child's choice is not favourable to the child, in the child's interests, the judge may change the verdict and determine which is suitable for the child.

Divorce is a terrifying scourge for every family (husband, wife, and children). The causes of divorce can vary, namely, failure to communicate, infidelity, domestic violence, economic problems, early Marriage, cultural change, etc. Post-divorce, both parties (ex-husbands and ex-wives) must make adjustments to their new lives. Especially financial issues, especially from the Marriage between them have been born children. If the parents' family are good, get along well and care, the child will get a positive element of his personality. If his parents are religious and obedient to carry out religion in daily life, they receive a spiritual experience that becomes an element in his nature.

Article 9 of Law No.4 of 1979 on child welfare states that parents are the first to be responsible for realising children's interest both physically, physically and socially. Parental responsibility for the welfare of the child contains the obligation to nurture and educate the child in such a way so that the child can grow and develop into an intelligent, healthy, devoted person to the parents, virtuous, godly to God almighty and willful, and able to continue the ideals of the nation based on Pancasila.

Child-rearing also means a parent's responsibility to supervise, provide good services and meet the needs of the child's life from his parents. The obligation to do maintenance of the child is fixed until the child can stand alone. In some laws and regulations, we can see several things that govern parents' obligation to children: Parental responsibilities to children after divorce according to marriage Law No. 1 of 1979.

Legally the obligation between husband and wife will arise if the Marriage has been performed or performed. In other words, a wife or husband's obligation will not exist if a man or woman has not achieved Marriage. The obligations and rights are balanced between husband and wife when coupled with the same commitment to build and enforce the household expected to be the basis in building a home.

The shared obligation between husband and wife in building and establishing a household will wear off when the family is shaken and even worse when the home disbands, concerning this matter has previously existed and is regulated in the Marriage Law. The child is the trust of God that must be cared for, nurtured and educated with compassion. Educating children is an essential parental obligation that will strongly influence the child's development in the latter days. That obligation includes physical and spiritual education that begins as early as possible. So it must be accounted for by every parent in various aspects of his life.

Education needs to be seen as a process that continues, develops, and simultaneously with the individual development of a child who learns anything in his environment. With the skills he obtained, the child will apply it in various contexts in his daily life or as a preparation for his life in the future. From an Islamic perspective, children's education is the process of educating, nurturing and training their physical and spiritual that parents do as their responsibility to the child based on sound values and praise sourced from the Qur'an and 
Sunnah. Even in Islam, the family education system is seen as determining the future of the child. To the extent that it is claimed that the paradise of hell the child depends on his parents.

The intention is to give birth to a child who becomes a generation of people who Rabbani who believe, trust, and do righteous deeds is parents' responsibility. According to Islam's concept, the child is born fitrah, a sacred initial condition that is to be pretentious to good but in the knowledge he does not know anything. Nevertheless, God's essential capital for the development of knowledge and attitude has been given, namely how many sense, mind, and heart instruments. There is under the Word of Allah SWT, in surah An-Nahl verse 78 as follows: "And God brought you out of the belly of your mother in a state of not knowing anything, and He gave you hearing, sight and heart, that you may be grateful".

Family is the first and foremost place of education for a person, and parents as the key. Education in the family mainly plays a role in developing character, personality, cultural values, religious and moral values, and simple skills. Education in this context has the meaning of culture, namely the process of socialisation and enculturation in a sustainable manner to bring children to be human beings who believe, have faith, noble character, independent, creative, innovative, work ethic, loyal friends, care for the environment and so on.

Parents educate their children by paying attention to their potential. Therefore, parents' role in educating children is done by guiding, helping or directing them so that they know the norms and life goals that they want to achieve. Parents or mothers and fathers play an important and very influential role in the education of their children. Ever since a child was born, it's his mother who's always been by his side. Therefore the child imitates his mother's temper, and usually, a child is more in love with his mother. When the mother does her job well. The father's influence on his son is also significant. In his son's eyes, a father becomes the highest role model and becomes the focus among the people he knows. So that what his father does will affect his children's attitude, including when the father does his daily work will affect the way his son works.

The family is an institution formed because of marital ties. In it lives with a married couple legally because of Marriage. They live together as life as dead, light as carrying, weight equally carried, always get along well and peacefully with a determination and aspiration to form a happy and prosperous family born and inwardly. The family is an essential forum between individuals and groups and is the first social group in which children become members. And the family is undoubtedly the first thing to be placed on socialising the lives of children, mothers, fathers and siblings and other families, and parents are the first to make contact and teach those children as they live with others. So that whatever parents guide their children, including religion, will follow children.

The facts stated above apply in family life or household. It shows the characteristics and character of every parent's sense of responsibility for their children's lives for the present and future. Even parents generally feel responsible for everything from the survival of their children. Therefore there is no doubt that the responsibility of education is fundamentally shared with parents. Whether the commitment of education is recognised consciously or not, accepted with all his heart or not, it is a fitrah that Allah SWT has affirmed to every parent. They cannot avoid that responsibility because it has been a mandate from God imposed upon them.

Furthermore, from the description above, it can be known that the responsibility for all costs of care and education of the child is fundamentally borne by both parents based on the interests of the child, whenever there is a dispute about the mastery of responsibility to the child of the court that gives the decision. Then basically, if there is a divorce between husband 
and wife, they remain responsible for the child to nurture and educate for the child's benefit. In such maintenance, although in practice carried out by one of them, it does not mean that the other party is independent of such maintenance responsibility.

In the event of a divorce, who has the right to take care of the child. In the hadith narrated by Ahmad and Abu Daud, there is an event, a woman went to the Messenger of Allah and said, "O Messenger of Allaah, my son is my belly who contains it, my care is watching over him, and my milk is drinking it. His father wanted to take it from me, so said the Messenger of Allah, you are more entitled to take care of the child, as long as you are not married to another man"." And Allah brought you forth from the bellies of your mothers while you knew nothing and gave you hearing and sight and hearts that haply ye may give thanks." (QS) An-Nahl: 78)

Family is the first and foremost place of education for a person, and parents as the key. Education in the family mainly plays a role in developing character, personality, cultural values, religious and moral values, and simple skills. Education in this context has the meaning of culture, namely the process of socialisation and enculturation in a sustainable manner to bring children to be human beings who believe, have faith, noble character, independent, creative, innovative, work ethic, loyal friends, care for the environment and so on. Parents educate their children by paying attention to their potential. Therefore, parents' role in educating children is done by guiding, helping or directing them so that they know the norms and life goals that they want to achieve.

Parents or mothers and fathers play an important and very influential role in the education of their children. Ever since a child was born, it's his mother who's always been by his side. Therefore the child imitates his mother's temper, and usually, a child is more in love with his mother. When the mother does her job well. The father's influence on his son is also significant. In his son's eyes, a father becomes the highest role model and becomes the focus among the people he knows. So that what his father does will affect his children's attitude, including when the father does his daily work will affect the way his son works. The family is an institution formed because of marital ties. In it lives with a married couple legally because of Marriage. They live together as life as dead, light as carrying, weight equally carried, always get along well and peacefully with a determination and aspiration to form a happy and prosperous family born and inwardly.

The family is a significant forum between individuals and groups and is the first social group in which children become members. And the family is undoubtedly the first thing that becomes the place to socialise the lives of children, mothers, fathers and siblings and other families, and parents are the first to make contact and the first to teach those children as they live with others. So that whatever parents guide their children, including religion, will follow children. The facts stated above apply in family life or household. It shows the characteristics and character of every parent's sense of responsibility for their children's lives for the present and future. Even parents generally feel responsible for everything from the survival of their children. Therefore there is no doubt that the responsibility of education is fundamentally shared with parents. Whether the commitment of education is recognised consciously or not, accepted with all his heart or not, it is a fitrah that Allah SWT has affirmed to every parent. They cannot avoid that responsibility because it has been a mandate from God imposed upon them.

Furthermore, from the description above, it can be known that the responsibility for all costs of care and education of the child is fundamentally borne by both parents based on the interests of the child, whenever there is a dispute about the mastery of responsibility to the child of the court that gives the decision. Then basically, if there is a divorce between husband and wife, they remain responsible for the child to nurture and educate for the child's benefit. In 
such maintenance, although in practice carried out by one of them, it does not mean that the other party is independent of such maintenance responsibility. Thus it is clear that in the event of a divorce, between the two persons sets for maintenance on the mother's part as long as the child has not puberty and married another man. The reason can be seen in Abu Bakr Siddiq's statement below: "Mothers are more inclined (patient) to children, smoother, more generous, more caring, better, and more compassionate.

\section{Conclusion}

The responsibility for all child maintenance and education costs is fundamentally borne by both parents based on the child's interests whenever there is a dispute over the mastery of commitment to the court's child that gives the decision. Then basically, if there is a divorce between husband and wife, they remain responsible for the child to nurture and educate for the child's benefit. In such maintenance, although in practice carried out by one of them, it does not mean that the other party is independent of such maintenance responsibility.

Regarding the system of liability of the father to the child can not be separated from the legislative policy contained in the marriage law. The regulation has listed several provisions on the responsibility of parents (especially fathers) to their children. UUP No.1 Year 1974 until now has not explicitly set about the mastery of children even in PP No. 9 the Year 1975 widely and in detail. So at that time, before 1989, the judges still use the books of fiqh. It was only after the enactment of The Religious Justice Law No. 7 of 1989 and Presidential Decree No. 1 of 1999 on the dissemination of KHI. The issue of hadhanah became a positive law in Indonesia, and the religious judiciary was authorised to examine and resolve it.

\section{References}

[1] Adib,B. (2012), Prosedur Gugatan Cerai Pembagian Harta Gono Gini+ Hak Asuh Anak, Yogyakarta: Pustaka Indonesia,Jakarta Balai Pustaka.

[2] Prakoso, D., (1987), Azas-Azas Hukum Perkawinan di Indonesia. Jakarta, Bina Aksara.

[3] Satrio, J., (2005). Hukum Keluarga Tentang Kedudukan Anak Dalam Undang-Undang. Bandung : Citra Aditya Bakti.

[4] Sayuti, T,(1974), Hukum Kekeluargaan Indonesia. Jakarta: Universitas Indonesia.

[5] Soetandyo,W., (2013) Hukum Konsep Dan Metode,Setara Press,Malang.

[6] Wadong, M.H.(2000),Advokasi dan Hukum Perlindungan Anak Jakarta: Grasindo Widya Sarana Indonesia. 2000

[7] Wiryono, P., (1984), Hukum Perkawinan di Indonesia,Sumur, Bandung

[8] Yustisia.Kansil, C.S.T., (1979) Pengantar Ilmu Hukum dan Tata Hukum Undang undang Hukum Perdata (BW)

[9] Undang - undang Nomor 35 Tahun 2014 tentang Perubahan atas Undang-Undang nomor 23 tentang Perlindungan Anak.

[10] Undang- undang Nomor 4 Tahun 1979 tentang Kesejahteraan Anak

[11] Undang - undang Nomor 3 Tahun 1997 Tentang Undang-undang Pengadilan Anak

[12] Undang - Undang Nomor 1 Tahun 1974 Tentang Perkawinan

[13] UU No. 23 tahun 2004 Tentang Penghapusan Kekerasan Dalam Rumah Tangga

[14] Ilmu Faraidh, A.Hasan Panduan Praktis Hukum Waris Menurut Al-Qur'an dan Sunnah, M.bin Shalih al-Utsaimin, Penerbit: Pustaka Ibnu Katsir 
[15] Mukti Arto, Praktek Perkara Perdata Pada Pengadilan Agama. Cetakan ke tiga. Yogyakarta: Pustaka Pelajar. 2000.

[16] Soemiyati. Hukum Perkawinan Islam dan UUP (Undang-Undang Nomor 1 Tahun 1974 tentang Perkawinan), Yogyakarta:Liberty. 1982.

[17] Undang-Undang Nomor 2 Tahun 1986 Tentang Peradilan Umum.

[18] Undang-Undang Nomor 4 Tahun 2004 Tentang Kekuasaan Kehakiman.

[19] Undang-Undang Nomor 3 Tahun 2006 Tentang Perubahan Atas Undang-Undang Nomor 7 Tahun 1989 Tentang Peradilan Agama.

[20] Peraturan Pemerintah Nomor 9 tahun 1975 Tentang Pelaksanaan Undang-Undang Nomor 1 Tahun 1974 Tentang Perkawinan

[21] Undang-undang Republik Indonesia Nomor 1 Tahun 1974Tentang Perkawinan (Bandung: Citra Umbara, 2007).

[22] J. Satrio, Hukum Keluarga Tentang Kedudukan Anak Dalam Undangundang.(Bandung : PT. Citra Aditya Bakti, 2000), hlm. 5.

[23] Riduan Syahrani, Seluk Beluk dan Asas-Asas Hukum Perdata, (Bandung : Penerbit Alumni, 1989), 100-101.

[24] Team Nusantara, Kitab Undang-Undang Hukum Perdata, (Jakarta: Nusantara Publisher, 2009) 25.

[25] Hilman Hadikusuma, Hukum Perkawinan Indonesia Menurut; Perundangan, Hukum adat, dan Hukum, (Agama, Erlangga, Jakarta, 2003) 133.

[26] Syafran Sofyan SH, SpN, MHum," Analisis Putusan MK," http//hukum online.(diakses pada 01-08-2014).

[27] Sudarsono, Hukum Kekeluargaan Nasional (Jakarta: Rineka Cipta, 1991) 23 